\title{
Analytical methods in herpesvirus genomics
}

\author{
Jana Blaškovičová, Ján Labuda \\ Institute of Analytical Chemistry, Faculty of Chemical and Food Technology, \\ Slovak University of Technology in Bratislava, Radlinského 9, SK-812 37 Bratislava, Slovak Republic \\ jana.blaskovicova@stuba.sk
}

(Presented at the XIII Ih Conference with International Participation "Present State and Perspectives of Analytical Chemistry in Practice", 1-4 June, 2014, Bratislava)

\begin{abstract}
Genomics is a branch of bioanalytical chemistry characterized as the study of the genome structure and function. Genome represents the complete set of chromosomal and extrachromosomal genes of an organism, a cell, an organelle or a virus. There are at least five from eight species of herpesviruses commonly widespread among humans, Herpes simplex virus type 1 and 2, Varicella zoster virus, Epstein-Barr virus and Cytomegalovirus. Human gammaherpesviruses can cause serious diseases including B-cell lymphoma and Kaposi's sarcoma. Diagnostics and study of the herpesviruses is directly dependent on the development of modern analytical methods able to detect and determine the presence and evolution of herpesviral particles/ genomes. Diagnostics and genomic characterization of human herpesvirus species is based on bioanalytical methods such as polymerase chain reaction (PCR), DNA sequencing, gel electrophoresis, blotting and others. The progress in analytical approaches in the herpesvirus genomics is reviewed in this article.
\end{abstract}

Keywords: analytical methods, genomics, herpesvirus

\section{Introduction}

Herpesviridae is a large family of DNA viruses which can establish latent and/or lytic infection in mamals, including humans (Mettenleiter et al. 2008). They are causative agents of various diseases. More than $90 \%$ of adults have been infected with at least one or more herpesviruses (Chayavichitsilp et al. 2009). All studied herpesviruses share the typical particle morphology, and the ability to establish lifelong infection of the host (Subak-Sharpe and Dargan 1998). In some host cells accumulate latency-associated gene transcripts, thus establishing a period of latency. Lytic infection is characterized by producing infectious viral particles and is transcriptionally controlled. Reactivation of the latent virus is usually associated with malaise and typically leads to the death of the cell, but does not necessarily lead to any notable symptoms (Grinde 2013). Some of the herpesvirus genomes exist in the form of episomes (EBV).

Herpesviruses consist of at least 8 species of herpesviridae categorized into three subfamilies, such as alpha, beta, and gamma herpesviruses. The alpha subfamily primarily target neurons for long-term residency, but they are able to replicate also in epithelia to established efficient transmission through skin or mucosa. The beta and gamma subfamilies prefer various subsets of leukocytes, but they can infect epithelial cells too. Alpha herpesvirus includes herpes simplex virus type 1 and 2 (HSV-1 and HSV-2), and varicella zoster virus (VZV). HSV usually causes oral and/or genital her- pes while VZV causes varicella (chickenpox) after acute infection becomes latent in ganglionic neurons. With advancing age or immunosuppression, cell-mediated immunity to VZV declines and the virus reactivates to cause herpes zoster (shingles), which is often complicated by chronic pain (PHN), cranial nerve palsies, zoster paresis, vasculopathy, meningoencephalitis, myelopathy, and multiple ocular disorders (Gilden et al. 2011). Beta herpesvirus includes cytomegalovirus (CMV), human lymphotropic virus (HHV-6), and human herpesvirus 7 (HHV-7). CMV causes infectious mononucleosis like syndrome and retinitis. Human cytomegalovirus (HCMV) is a ubiquitous herpesvirus displaying no signs or only mild symptoms and no long-term health consequences during its life-long latency in healthy individuals. Nevertheless, HCMV causes severe congenital abnormalities in neonates and fatal opportunistic infections in immunosuppressed patients (Britt 2008). HHV-6 causes roseola infantum or exanthema subitum. A role for HHV-6 has been proposed in several autoimmune diseases (AD) including multiple sclerosis (Voumvourakis et al. 2010), autoimmune connective tissue diseases (Broccolo et al. 2013), and Hashimoto's thyroiditis (Caselli et al. 2012). HHV-6 infection might be related also to the onset of autoimmune disorders, including Sjogren's syndrome (Ranger-Rogez et al. 1994), purpura fulminans, severe autoimmune acquired protein S deficiency (Boccara et al. 2009), severe and acute autoimmune hepatitis (Potenza et al. 2008, Grima et al. 2008), and autoimmune hemolytic anemia/neutropenia (Yagasaki et al. 2011). 
Gammaherpesviruses are the only ones associated with malignancies. They include Epstein-Barr virus (EBV) and Kaposi's sarcoma-associated herpesvirus (KSHV). EBV causes infectious mononucleosis and is a causal agent in a number of malignancies in humans including nasopharyngeal carcinoma, the endemic form of Burkitt's lymphoma (BL), Hodgkin's disease, and a small percentage of gastric carcinomas (Kieff E 1996, Thompson and Kurzrock 2004). Kaposi sarcoma-associated herpesvirus (KSHV) also known as Human herpesvirus 8 (HHV8), is the etiological agent of several human malignancies including Kaposi's sarcoma (KS), primary effusion lymphoma (PEL), and multicentric Castleman's disease (Cesarman et al. 1995, Chang et al. 1994, Soulier et al. 1995, Whitby et al. 1995, Whitley et al. 1998). The virus is able to modulate cell pro-proliferative pathways to its advantage, while simultaneously inhibiting pro-apoptotic signaling pathways (Dittmer and Damania 2013). The model organism for study human gammaherpesviruses and associated malignancies is murine herpesvirus (MuHV). All human herpesviruses and the most prevalent human herpesvirus associated diseases are listed in Table 1.

The study of the herpesviruses is directly dependent on the development of modern analytical methods able to detect and determine the presence and evolution of herpesviral particles/genomes. Genomics is a branch of bioanalytical chemistry characterized as the study of the genome structure and function. Genome represents the complete set of chromosomal and extrachromosomal genes of an organism, a cell, an organelle or a virus while gene is a part of deoxyribonucleic acid (DNA) able to code for a protein. DNA is a biomolecule that encodes the genetic information of living organisms and many viruses including herpesvirus species. Herpesviruses comprise double stranded DNA genome ranging in size 120-240 kbp (Fossum et al. 2009).

Diagnostics and genomic characterization of human herpesvirus species is based on bioanalytical methods such as polymerase chain reaction, DNA sequencing, gel electrophoresis, blotting and others. The complete list of analytical methods described in this review used to analyze the herpesvirus genomes is listed in Table 2.

Polymerase chain reaction (PCR) is one of the most widespread analytical methods in herpesvirus genomics. This method can amplify few copies of DNA generating up to millions copies of a particular DNA sequence. It was developed in 1983 by Kary Mullis (Mullis and Faloona 1987) and can be used for DNA amplification prior to sequencing, functional analysis of the genes, detection/diagnosis of hereditary and infectious diseases and identification of genetic fingerprints. Based on PCR testing of patients DNA we can study and describe the pathogen distribution in the population. PCR assay is one of the most sensitive tests currently available to detect HSV in clinical samples (LeGeoff et al. 2014). There are various PCR-based methods in to the clinical laboratory, like conventional PCR, nested PCR, real-time PCR and quantitative PCR, which have been established as easily available assays with the advantage of rapidity and low contamination rate. Nested PCR increases the specificity of template amplification by using two sets of the primers

Tab. 1. Human herpesviruses.

\begin{tabular}{|c|c|c|c|}
\hline $\begin{array}{l}\text { Human } \\
\text { herpes type }\end{array}$ & Name & Sub Family & Associated diseases \\
\hline HHV-1 & Herpes simplex 1 (HSV-1) & Alphaherpesvirinae & $\begin{array}{l}\text { Oral herpes } \\
\text { Genital herpes (predominantly orofacial) }\end{array}$ \\
\hline HHV-2 & Herpes simplex 2 (HSV-2) & Alphaherpesvirinae & $\begin{array}{l}\text { Oral herpes } \\
\text { Genital herpes (predominantly genital) }\end{array}$ \\
\hline HHV-3 & Varicella Zoster virus (VZV) & Alphaherpesvirinae & $\begin{array}{l}\text { Chickenpox } \\
\text { Shingles }\end{array}$ \\
\hline HHV-4 & Epstein-Barr virus (EBV) & Gammaherpesvirinae & $\begin{array}{l}\text { Mononucleosis } \\
\text { Burkitt's lymphoma } \\
\text { post-transplant lymphoproliferative syndrome } \\
\text { nasopharyngeal carcinoma }\end{array}$ \\
\hline HHV-5 & Cytomegalovirus (CMV) & Betaherpesvirinae & $\begin{array}{l}\text { Mononucleosis like syndrome } \\
\text { Retinitis }\end{array}$ \\
\hline HHV-6 & Human lymphotropic virus & Betaherpesvirinae & $\begin{array}{l}\text { Roseola infantum } \\
\text { Exanthema subitum }\end{array}$ \\
\hline HHV-7 & Human herpesvirus 7 (HHV-7) & Betaherpesvirinae & Pitiriasis rosea \\
\hline HHV-8 & $\begin{array}{l}\text { Kaposi's sarcoma-associated } \\
\text { virus (KSHV) }\end{array}$ & Gammaherpesvirinae & $\begin{array}{l}\text { Kaposi's sarcoma primary effusion lymphoma } \\
\text { Castleman's disease }\end{array}$ \\
\hline
\end{tabular}


Tab. 2. Analytical methods in herpesvirus genomics.

\begin{tabular}{ll}
\hline Method & Method specification \\
\hline Polymerase chain reaction (PCR) & Basic PCR \\
& Nested PCR \\
& Real time PCR \\
& Quantitative PCR \\
& Sanger sequencing \\
Sequencing & Ion Torrent \\
& Pyrosequencing \\
& Next generation sequencing \\
& Illumina \\
& Agarose GE \\
Gel electrophoresis (GE) & Acrylamid GE \\
& Southern blotting \\
Blotting & Northern blotting \\
Other & Restriction fragment length polymorphism (RFLP) \\
& Use of biosensor \\
& Use of nanoparticles \\
\hline
\end{tabular}

(outer and inner). Nested PCR is more successful in specifically amplifying long DNA fragments. Real time PGR is a PCR technique which simultaneously amplifies and quantifies a targeted DNA molecule (Wilhelm and Pingoud 2003). Quantitative PCR is used to measure the quantity of a target DNA, cDNA or RNA sequence in real-time, thus determining whether a DNA sequence is present in a sample as well as the number of its copies in the sample. Real time quantitative reverse transcription PCR enables reliable detection and measurement of products generated during each cycle of PCR process. PCR based techniques, particularly in CNS infection, have replaced the gold standard for the diagnosis of HSV-1, HSV-2 and VZV, because cerebrospinal fluid stays positive for up to 1 week after the infection (Whitley and Roizman 2001). Polymerase chain reaction (PCR) or multiplex PCR was performed for HHVs detection, including HSV-1 and -2, VZV, CMV, EBV, HHV-6 and -7. This analytical approach determined high rate of virus detection (more than $98 \%$ ) and virus co-infection (more than $80 \%$ ) in induced sutum samples from hospitalized infants and children with respiratory illness. (Zhou et al. 2013).

DNA sequencing is a process used to determine the nucleotide sequence. The method based on selective incorporation of chain-terminating dideoxynucleotides is called Sanger sequencing. The Sanger sequencing method was found by Frederick Sanger in 1977 (Sanger et al. 1977) and forms the basis of automated sequencing reactions till today. Another analytical approach was used in the method of pyrosequencing which is a sequencing method based on the pyrophosphate release detection through the nucleotide incorporation (sequencing by synthesis method). The desired DNA sequence is able to be determined by light emission. Next-generation sequencing (NGS) approaches have several advantages over previous detection methods. They are highly sensitive and highly specific, since the sequence for each read represents a fingerprint for a particular organism. Another advantage is that a broad assessment of all known organisms can be performed in a single assay. This technology not only helps better identify etiological agents, but it can also better define cancers and/or specimens that are truly not associated with any known viruses (Strong et al. 2013). One of the NGS methods is Ion Torrent sequencing technology, which directly translates chemically encoded information (A, C, G, $\mathrm{T})$ into digital information $(0,1)$ on a semiconductor chip. The result is a sequencing technology that is simpler, faster, more cost effective and scalable than any other technology available. If a nucleotide, for example a $\mathrm{C}$, is added to a DNA template and is then incorporated into a strand of DNA, a hydrogen ion will be released. The charge from that ion will be transformed from chemical to digital information. Another from the NGS methods is illumina sequencing. It is based on reversible dye-terminators that enable the identification of single bases through their introduction into DNA strands. Due to the automation of this method it is possible to gain sequencing data quickly and to sequence multiple strands at once. Illumina sequencing is employed to sequence difficult regions like homopolymeres and repetitive sequences, but also genomes and can be used for methylation profiling and genome wide protein-NA (nucleid acid) interaction analysis.

Gel electrophoresis (GE) is a method for separation and analysis of macromolecules (DNA) 
and their fragments according to their size and charge. According to the material used for the gel electrophoresis we distinguish agarose GE or polyacrylamid GE. A method of transferring DNA or RNA from the gel to the carrier (nitrocellulose or nylon membrane) is called Southern or Northern blotting.

There is a lot of other analytical approaches like restriction length polymorphism (RFLP) and use of biosensors and nanoparticles, helping to put new insights into the herpesvirus genome problematics. RFLP is an analysis using enzymes (restriction endonucleases) to digest DNA into pieces (restriction fragments) which are separated by gel electrophoresis according to their size. The biosensors are analytical devices that by the help of immobilized biocomponent (DNA, oligonucleotide) convert biochemical information into the analytical signal. They represent effective tools for the study of biomolecules (nucleid acids) structure and function. Similarly, nanoparticles (NP) which represent solid colloidal particles ranging in size from 1 to $100 \mathrm{~nm}$, are utilized as drug delivery agents (Lockman et al. 2002). In interaction with biomolecule (part of the genome sequence), NP can act as a therapeutical (antiviral) drug (Lee et al. 2014).

The aim of this paper is to review the development of bioanalytical methods in the herpesvirus genomics achieved within a period of the last years.

\section{Analytical methods in herpesvirus genomics}

\section{Alphaherpesvirus genomics}

In clinical laboratory, conventional methods for detecting HSV-1, HSV-2 and VZV alphaherpesviruses such as cell culture or direct immunofluorescent assay have limitations such as slowness, insensitivity, and nonstandardization in interpretation (Gleaves et al. 1989). Using traditional methods, illness differences according to viral species require even more time, labor, and cost (Whitley and Roizman 2001, Sauerbrei and Wutzler 2007). HSV DNA detection based on nucleic acid amplification and PCR has emerged as an alternative method because it is about four times more sensitive, less dependent on collection and transport conditions, and faster than viral culture (Wald et al. 2003). Based on PCR analysis of patients we can study and describe the herpesvirus distribution in the population.

The PCR analysis provided the correct final diagnosis in 20 cases according to HSV-1, HSV-2 and VZV pathogens (Scheepers 2013). Together with CMV, they are the commonest pathogens responsible for infectious posterior uveitis and panuveitis (McCan- nel et al. 1996). The PCR primers targeting for a type-specific DNA sequence within the HSV glycoprotein $\mathrm{G}$ gene were approved for the detection and differentiation of HSV-1 and HSV-2. The sensitivity of PCR HSV-2 detection was $97.0 \%$. For HSV-1, the sensitivity range was 96.7-100\% (Van Der Pol et al. 2012).

High analytical sensitivity of the HSV and VZV detection was achieved also by the method of a duplex nested-PCR assay that allowed the detection of 5 copies/ $\mu \mathrm{L}$ for HSV and 10 copies/ $\mu \mathrm{L}$ for VZV (Rodrigues et al. 2013). VZV diagnosis is confirmed by the presence of VZV DNA or anti-VZV IgG, or both in cerebrospinal fluid (CSF) (Gilden et al. 1994). In the absence of rash, PCR examination for the presence of VZV DNA should be done (Gilden et al. 2013).

PCR-RFLP was applied for the detection of HSV (genes encoding for DNA polymerase) and VZV (genes encoding for thymidine kinase) (Kido et al. 1991, Rozenberg and Lebon 1991). PCR fragments were digested with restriction endonucleases SmaI and BamH I for HSV-1 and HSV-2 and Sma I only for VZV and visualized on $2 \%$ agarose gel electrophoresis to detect the fragmentation. Rapid and exact laboratory detection of these virus infections is important for diagnosis, as prompt antiviral therapy improves morbidity and mortality (Long 2013). Real time PCR, RFLP and gel electrophoresis analytical methods were used to clinically discriminate monkeypox (MPX) from severe form of chickenpox and from smallpox. Specimens consisting of liquid vesicle dried on filter papers or crusted scabs from healing patients with skin rash were sampled by first responders. A MPXV-specific pyrosequencing was carried out in order to confirm the results. Electrophoresis of all PCR products was done. This experience of rapid on-site dual use DNA-based differential diagnosis of rash illnesses demonstrates the potential of combining tests specifically to identify bioterrorism agents and agents causing natural outbreaks (Dumont 2014).

Detection of HSV-1/2 DNA in clinical specimens by real-time PCR did not need nucleic acid extraction/ purification prior to analysis. There is a study comparing real time PCR analysis of the HSV samples when analyzed in the extracted or unextracted form. The limit of detection of HSV-1 and HSV-2 particles, when analyzed in the unextracted form, was found to be approximately 17 and 32 virus particles, respectively. The sensitivity of 10 copies was achieved for analysis of purified DNA (Pandori 2006). There is another study showing that it is feasible to test non-extracted HSV in a real-time PCR (Miari et al. 2014). Omission of the nucleic acid extraction step shortened both the assay time and cost. 
Real time PCR and melting curve analysis, used for HSV-1, HSV-2, and VZV detection, clearly indicated increased diagnostic sensitivity compared to the shell vial culture. In comparison with PCRRFLP, real-time PCR and melting curve analysis demonstrated a modest increased sensitivity. In this study, real-time PCR using SYBR green dye was chosen since it does not require setting new probes and intercalates double-stranded DNA fluorescent signals as PCR progresses, thus detecting the presence of target DNA. This method have increased sensitivity, shortened turnaround time in clinical samples and help the rapid diagnosis and prompt treatment for patients (Hong YJ et al. 2014).

Using Real-time Fluorescent Quantitative PCR authors revealed that Hsp90, that is involved in HSV-1 early infection, by interacting with acetylated $\alpha$-tubulin, plays a crucial role in promoting viral nuclear transport. Hsp90 inhibitors suppressed drug-resistant HSV-1 replication by interfering with the interaction between Hsp90 and $\alpha$-tubulin, thereby inhibiting capsid nuclear translocation and replication, thus offering a promising strategy against drug-resistant HSV-1 infection (Zhong et al. 2014).

The analytical method of preparation $\mathrm{SiO} 2$ nanoparticles (SiNPs) encapsulated LL-37 incorporated into collagen-MPG (2-methacryloyloxyethyl phosphorylcholine) hydrogel was used for the examination of the antimicrobial and antiviral (anti HSV-1) activity of human cathelicidin. HSV-1 is the main infectious cause of vision loss and blindness worldwide (Choudhary et al. 2008). In the eye a 37 amino acid C-terminal peptide domain (LL-37) of the only one human cathelicidin, the 18 -kDa human cationic antimicrobial protein (hCAP18), with active antimicrobial and antiviral activity (Lehrer et al. 2002) is expressed by the cornea epithelium. LL-37 has been reported to have potent antiviral activity against HSV-1 (Gordon et al. 2005). LL-37 released from composite $\mathrm{SiO}_{2}$ nanoparticle-hydrogel corneal implants showed anti-HSV-1 activity by blocking virus binding (Lee et al. 2014).

\section{Betaherpesvirus genomics}

HHV-6 is an emerging pathogen that has not been defined as an oncogenic pathogen but has been variably associated with lymphomas using traditional detection methods (e.g., PCR, Southern blotting, and immunohistochemistry) (Ogata 2009). Human herpesvirus 6 (HHV-6) is a ubiquitous pathogen infecting nearly $100 \%$ of the human population. $0.2 \%-1 \%$ of them carry chromosomally-integrated HHV-6 (ciHHV-6). The biological consequences of chromosomal integration by $\mathrm{HHV}-6$ remain unknown. Panels of DNA samples were screened by polymerase chain reaction (PCR) for the presence of U11 or U18 sequences of human telomeres integrated copy of HHV-6. These telomeres are often short and unstable, facilitating release of the viral genome from the chromosome (Huang et al. 2014). Single PCR products were reamplified, gel purified and sequenced by the Sanger dideoxy termination method. Overlapping amplicons across the unique region of were prepared for sequence analysis using an IonTorrent personal genome sequencer. HHV-6 DNA was separated by gel electrophoresis in $0.4 \%$ agarose and a Southern blot was prepared and hybridized to a phospho-labelled telomere probe. Using this analytical approach, the authors have shown that the HHV-6-associated telomere is often one of the shortest in somatic cells and its presence increases the chance that the cell will become senescent, thus affecting tissue homeostasis (d'Adda di Fagagna et al. 2003, Kaul et al. 2012). Cells carrying critically short telomeres associated with HHV-6 may be prone to telomere fusion events that can drive instability. The integrated copies of HHV-6 can be excised from the chromosome thus facilitate spreading to another telomere within the cell or represent the viral reactivation (Huang Y et al. 2014). By another authors, Quantitative TaqMan PCR (QPCR) using HHV-6 specific primers and probe was used to analyze 293 DNA samples from children with acute lymphoblastic leukemia compared to healthy blood donors offer the presence of ciHHV-6 viral DNA. 287 samples from diseased children contained amplificable viral DNA but only $1(0.35 \%)$ contained ciHHV-6. None of the 288 DNA samples from healthy individuals contained ciHHV-6 (Gravel et al. 2013).

Comprehensive viral genome analysis of RNA sequence (RNA-seq) data sets from 118 non-Hodgkin's B-cell lymphomas using the next-generation sequencing approach revealed a small subset that is positive for Epstein-Barr virus (EBV) or human herpesvirus 6 (HHV-6) with one coinfection (Strong et al. 2013).

By means of PCR, there was performed study to compare the incidence of $\mathrm{CMV}$ and $\mathrm{EBV}$ viral infections in de novo kidney transplant patients, receiving either belatacept or cyclosporine. Patients were tested for cytomegalovirus, Epstein-Barr virus infections monthly for 36 months. The number of positive cytomegalovirus, over the number of polymerase chain reactions performed through all 3 years was similar in both groups. The number of Epstein-Barr virus primary infection was similar in both groups, while the number of Epstein-Barr virus reactivation was higher in the belatacept group. Using this simple analytical approach authors 
identified that Epstein-Barr virus replication occurs more often in patients receiving belatacept, than it does in those receiving cyclosporine (Bassil et al. 2014).

CMV PCR of the bronchoalveolar lavage from the lungs of children with pneumonia detected the presence of $\mathrm{CMV}$ with $82 \%$ detection rate (Restrepo-Gualteros et al. 2014). CMV pneumonia is a potential lethal disease in infected children. CMV caused respiratory failure in $47 \%$ of children infected and the overall mortality rate was 13.3 (Restrepo-Gualteros et al. 2014). By using real-time PCR of the $p p 65$ gene which encodes for a $65 \mathrm{kDa}$ tegument protein (reported to be a target of immune response during natural infection of this virus), acute pulmonary human cytomegalovirus (HCMV) infection in children was diagnosed (Liu et al. 2014).

Utilizing analytical methods of blotting (Northern blotting), sequencing (cDNA library screening), PCR and agarose gel electrophoresis a family of novel 3' coterminal transcripts from the UL30-UL32 gene region of HCMV were recognized (Ma et al. 2013). Detailed mapping of HCMV transcripts may provide important information for understanding the virus-host interactions between HCMV. Further investigation on the novel transcripts may offer new strategies for HCMV treatment.

Congenital (CI) and perinatal cytomegalovirus (CMV) infections (PI) can be linked to maternal CMV seropositivity, with fatal consequences in preterm newborns. Analysing the saliva samples by the analytical methods such as PCR (qualitative PCR and nested PCR) and agarose gel electrophoresis, neonatal CMV was found in $5.1 \%$ of newborns. The maternal CMV-positive IgG serology was $97.3 \%$. CMV PI and CI in preterm infants from highly seropositive mothers was high, but the rate of symptomatic infection was low, thus supporting the need of the virus prevalence screening (ArellanoGalindo et al. 2014)

\section{Gammaherpesvirus genomics}

Gammaherpesviruses such as EBV and KSHV are widespread pathogens that establish lifelong infections and are associated with the development of numerous types of diseases, including cancer. In most tumors, EBV exists as an autonomously replicating episome. Episomal replication and segregation during mitosis is facilitated in part by the Epstein-Barr virus nuclear antigen 1 (EBNA1) (Lee et al. 1999, Young et al. 2000). Long term culture and clonal selection, or treatment with hydroxyurea can lead to the loss of EBV episomes in EBV positive Burkitt's lymphoma cell lines (BLs) (Chodosh et al. 1998, Komano et al. 1998, Shimizu et al. 1994). The reintroduction of EBV into EBV negative BLs reconstitutes the tumor phenotype, thus EBV-induced cellular genes play critical role in EBV-related tumors. Using analytical approach of real time PCR authors verified higher expression of PLAC1 gene in EBV positive vs. EBV negative cell culture clones (Wang et al. 2014). Based on its expression profile and its localization to the $\mathrm{X}$ chromosome, PLAC1 is a candidate cancer antigen (Scanlan et al. 2002). Due to its localization on the surface of cancer cells, PLAC1 provides accessibility to antibodies make them attractive candidates for targeted immunotherapeutic approaches (Koslowski et al.2007).

Many oncogenic viruses exhibit cellular transforming properties, often involving activation of oncogenes and inactivation of tumor suppressor genes. The DOK1 gene is a newly identified tumor suppressor gene with altered expression via hypermethylation of its promoter in a variety of human cancers. Using the analytical approach of DNA Methylation real time PCR and pyrosequencing (Frommer et al. 1992) authors determined the direct involvement of EBV in the inhibition of DOK1 expression through increased DNA methylation, thus enabling cell proliferation induced by EBV and promoting both cell growth and apoptosis arrest (Siouda et al. 2014).

An analytical method for the study of presence and reactivation of $\mathrm{EBV}$ in immunocompetent patients is of high importance. PCR for testing EBV viral load is recommended when dealing with immunocompromised patients (Cattoir et al. 2014). The search for EBV-DNA by real time PCR in the case of EBV-related malignancy before therapy may be useful in the diagnosis, follow-up and prognostic evaluation. Serologic results should be supported by PCR in order to ascertain the presence of EBV reactivation in immunosuppressive patients (Karadağ Geçgel et al. 2012).

Some authors declined that due to the pre-analytical and analytical methodologies applied to sample processing and analysis, the presence of EBV could be missed in some of the previous studies (Germi et al. 2012). There is a study which used appropriately validated methods for both the pre-analytical and analytical detection of EBV DNA in order to provide improved standardized viral detection from different clinical samples (Cocuzza et al. 2014). Use of standardized commercial methods to obtain high-yield automated recovery of microbial nucleic acids from different clinical matrices (DNA extraction) (Loens et al. 2007, Perandin et al. 2009, Dundas et al. 2008) and accurate quantification of EBV EBNA-1 gene, using a previously described real time PGR assay (Polman et al. 2011) and a larger sample volume of cerebrospinal fluid (CSF), 
as compared to most previous studies, was done in order to increase the sensitivity of EBV DNA in CSF and peripheral blood samples of MS (multiple sclerosis) patients. CSF and peripheral blood samples were also further separated in cell-free and cell-associated components prior to EBV DNA detection, in order to distinguish between possible latent and lytic EBV infections. Sensitivity of the standardized EBV molecular detection assay used in this study allows detection down to 10 copies/ reaction or 120 copies/ml of the sample (Cocuzza et al. 2014).

There are methodologies for direct and indirect detections of a specific oligonucleotide for EpsteinBarr virus (EBV) using electrochemical techniques. The sequence of oligonucleotide probe (EBV1, $100 \%$ identical with the EBV genome) was grafted to the platform sensitized with poly(4-aminothiophenol). The hybridization reaction was carried out with the complementary target (EBV2) on the modified electrode surface. Ethidium bromide was used as the DNA intercalator. The oxidation peak currents of ethidium bromide increased linearly with the complementary sequences concentration values. This genosensor can detect $17.32 \mathrm{nmol} / \mathrm{L}$ of an oligonucleotide target and differentiate onebase mismatch (point mutation). The biosensor also displayed high specificity to EBV with elimination of interference from mixture additives and good stability (120 days) (Balvedi et al. 2014).

Nested PGR amplification of a 737 bp K1 KSHV gene fragment from peripheral blood cell was sequenced and phylogeneticaly analysed. According to data obtained the authors found high KSHV seroprevalence in the two major populations living in Southern and Eastern Cameroon with the presence of genetically diverse K1 subtypes (Betsem E et al. 2014).

Using analytical methods of PCR and gel electrophoresis (PCR products were run on $1.5 \%$ agarose gel and analyzed) in this study shoved the genetic evidence that ORF6 is essential for KSHV lytic replication (Peng C et al. 2014). KSHV encodes at least 8 open reading frames (ORFs) that play important roles in its lytic DNA replication, among which ORF6 encodes an ssDNA binding protein that has been proved to participate in origin-dependent DNA replication in transient assays.

An extensive transcription of the KSHV viral genome was demonstrated with gene expression profiling of KSHV transcripts using northern blots, custom oligonucleotide microarrays and real time PCR arrays (Chandriani et al. 2010, Dittmer 2003). In an attempt to extend the current knowledge of the coding capacity of the KSHV genome during the productive stage of infection, there is another analytical genomic approach to study the tran- scription and translation profiles of lytic KSHV using mRNA-sequencing, ribosome footprinting, and genomic DNA sequencing. When combined, these methods provide a comprehensive, highresolution view of gene regulation and expression dynamics (Ingolia et al. 2009, Ingolia et al. 2012, Stern-Ginossar 2012). This analytical approach generated a novel annotation of the KSHV genome confirming the presence and timing of expression of the majority of previously annotated ORFs, while revealing several novel genomic features including ribosome protection of non-coding RNAs, new splice variants, and a plenty of upstream and small ORFs. In addition, authors confirmed and expanded the annotation of transcription start sites, polyadenylation sites, and initiation/termination codons of multiple known ORFs (Arias et al. 2014).

Next-Generation Sequence Analysis of the genome of the Macaque Homolog of Kaposi's Sarcoma (KS)-Associated Herpesvirus from a KS-Like Tumor sequenced on an Illumina Genome Analyzer II was accomplished. Twenty gaps remained in the sequence, which were targeted for PCR amplification sequenced providing Sanger sequencing method. This analytical approach revealed the whole genomic sequence of the KSHV Macaque Homolog (Bruce et al. 2013).

Quantitative real time PCR can determinate the viral DNA load in the supernatants of cultured lymphoma cell lines, thus providing a validated drug susceptibility assays for the screening and evaluation of candidate drugs against HHV-6, HHV-8, and EBV, as these viruses do not induce the formation of plaques in cell culture (Bounaadja et al. 2013).

Murine gammaherpesvirus (MHV 68) serves as the model organism for the gammaherpesvirus study. Analytical method of quantitative real time PCR in vivo demonstrated that the MHV68 miRNAs were dispensable for short-term virus replication but were important for establishment of lifelong infection in the key virus reservoir of memory B cells and essential for the development of virusassociated pneumonia, implicating them as a critical component of gammaherpesvirus-associated disease (Feldman et al. 2014).

\section{Conclusions}

Conventional methods used for the detection of herpesviruses in clinical laboratory such as cell culture or direct immunofluorescent assay have limitations such as slowness, insensitivity, and nonstandardization in interpretation. Moreover, differentiation according to viral species requires time, 
labor, and cost. Within this paper, the utilization of common analytical methods for the herpesvirus genomic research, diagnosis and therapy including PCR, sequencing, GE, blotting and others (RFLP, biosensor, nanoparticles) was reviewed. The use of these analytical approaches is still of high interest. Examples of high attention paid today to the development of technologies that are simpler, faster, more cost effective, sensitive, specific and, if possible, automatized when compared to the conventional ones, are presented as an outlook of further development on this topic.

\section{Acknowledgement}

This publication was supported by courtesy of the Slovak Research and Development Agency under the contract No. APVV-0797-11.

\section{References}

Arellano-Galindo J, Villanueva-García D, Cruz-Ramirez JL, Yalaupari-Mejìa JP, Uribe-Gutiérrez G, VelazquezGuadarrama N, Nava-Frias M, Munoz-Hernández O, Mejía-Arangure JM (2014) Journal of Infection in Developing Countries 11.8(6): 758-767.

Arias C, Weisburd B, Stern-Ginossar N, Mercier A, Madrid AS, Bellare P, Holdorf M, Weissman JS, Ganem D (2014) PLoS Pathogens 10(1): e1003847.

Balvedi RP, Castro AC, Madurro JM, Brito-Madurro AG (2014) International Journal of Molecular Sciences 15(5): 9051-9066.

Bassil N, Rostaing L, Mengelle C, Kallab S, Esposito L, Guitard J, Cardeau-Desangles I, Weclawiak H, Izopet J, Kamar N (2014) Experimental and Clinical Transplantation 12(3): 212-219.

Betsem E, Cassar O, Afonso PV, Fontanet A, Froment A, Gessain A (2014) PLoS Neglected Tropical Diseases 8(5): e2851.

Boccara O, Lesage F, Regnault V, Lasne D, Dupic L, Bourdon-Lanoy E, Pannier S, Fraitag S, Audat F, Lecompte T, Hubert P, Bodemer C (2009) British Journal of Dermatology 161(1): 181-183.

Bounaadja L, Piret J, Goyette N, Boivin G (2013) Journal of Clinical Microbiology 51: 1244-1246.

Britt W (2008) Current Topics Microbiology Immunology. 325: 417-470.

Broccolo F, Drago F, Cassina G, Fava A, Fusetti L, Matteoli B, Ceccherini-Nelli L, Sabbadini MG, Lusso P, Parodi A, Malnati MS (2013) Journal of Medical Virology 85(11): 1925-1934.

Bruce AG, Ryan JT, Thomas MJ, Peng X, Grundhoff A, Tsai CC, Rose TM (2013) Journal of Virology 87(24): 13676-13693.

Caselli E, Zatelli MC, Rizzo R, Benedetti S, Martorelli D, Trasforini G, Cassai E, degli Uberti EC, Di Luca D, Dolcetti R (2012) PLoS Pathogens 8(10): e 1002951

Chandriani S, Xu Y, Ganem D (2010) Journal of Virology 84: 7934-7942.

Cattoir L, Van Hende V, De Paepe P, Padalko E (2014) Acta Clinica Belgica Jun 10: 2295333714 Y0000000037.
Cesarman E, Chang Y, Moore PS, Said JW, Knowles DM (1995) New England Journal of Medicine 332: 1186-1191.

Chang Y, Cesarman E, Pessin MS, Lee F, Culpepper J, Knowles DM, Moore PS (1994) Science 266: 1865-1869.

Chayavichitsilp P, Buckwalter J, Krakowski A, Friedlande S (2009) Pediatrics in Review. 30: 119-129.

Chodosh J, Holder V, Gan Y, Belgaumi A, Sample J, Sixbey J (1998) Journal of Infectious Diseases 177: 1194-1201.

Choudhary A, Higgins GT, Kaye SB (2008) Cornea and External Eye Disease, Springer, Heidelberg.

Cocuzza CE, Piazza F, Musumeci R, Oggioni D, Andreoni S, Gardinetti M, Fusco L, Frigo M, Banfi P, Rottoli MR, Confalonieri P, Rezzonico M, Ferrò MT, Cavaletti G (2014) PLoS One 9(4): e94497.

d'Adda di Fagagna F, Reaper PM, Clay-Farrace L, Fiegler H, Carr P, Von Zglinicki T, Saretzki G, Carter NP, Jackson SP (2003) Nature 426: 194-198.

Dittmer DP (2003) Cancer Research 63: 2010-2015.

Dittmer DP and Damania B (2013) Current Opinion in Virology 3: 238-244.

Dumont C, Irenge LM, Magazani EK, Garin D, Muyembe JJT, Bentahir M, Gala JL (2014) PLoS One 9(5): e96930.

Dundas N, Leos NK, Mitui M, Revell P, Rogers BB (2008) Journal of Molecular Diagnostics 10: 311-316.

Feldman ER, Kara M, Coleman CB, Grau KR, Oko LM, Krueger BJ, Renne R, van Dyk LF, Tibbetts SA (2014) mBio 5(3): e00981-14.

Fossum E, Friedel CC, Rajagopala SV, Titz B, Baiker A, Schmidt T, Kraus T, Stellberger T, Rutenberg C, Suthram S, Bandyopadhyay S, Rose D, von Brunn A, Uhlmann M, Zeretzke C, Dong YA, Boulet H, Koegl M, Bailer SM, Koszinowski U, Ideker T, Uetz P, Zimmer R, Haas J (2009) PLoS Pathogens 5(9): e1000570.

Frommer M, McDonald LE, Millar DS, Collis CM, Watt F, Grigg GW, Molloy PL, Paul CL (1992) Proceedings of the National Academy of Sciences U S A. 89(5): 1827-1831.

Germi R, Lupo J, Semenova T, Larrat S, Magnat N, Grossi L, Seigneurin JM, Morand P (2012) Journal of Clinical Microbiology 50(4): 1384-1389.

Gilden D, Nagel MA, Cohrs RJ, Mahalingam R (2013) Current Neurology and Neuroscience Reports 13: 374-383.

Gilden D, Mahalingam R, Nagel MA, Pugazhenthi S, Cohrs RJ (2011) Neuropathology Applied Neurobiology 37: 441-463.

Gilden DH, Beinlich BR, Rubinstien EM, Stommel E, Swenson R, Rubinstein D, Mahalingam R (1994) Neurology 44(10): 1818-1823.

Gleaves CA, Rice DH, Bindra R, Hursh DA, Curtis SE, Lee CF, Wendt SF (1989) Diagnostic Microbiology and Infectious Disease. 12(4): 315-318.

Gordon YJ, Huang LC, Romanowski EG, Yates KA, Proske RJ, McDermott AM (2005) Current Eye Research 30: 385-394.

Gravel A, Sinnett D, Flamand L (2013) PLoS One 8(12): e84322.

Grima P, Chiavaroli R, Calabrese P, Tundo P (2008) Cases Journal 1: 110-112. 
Grinde B (2013) Journal of Oral Microbiology 25(5): doi 10.3402/jom.v5i0.22766.

Hong YJ, Lim MS, Hwang SM, Kim TS, Park KU, Song J, Kim EC (2014) BioMed Research International, doi $10.1155 / 2014 / 261947$.

Huang Y, Hidalgo-Bravo A, Zhang E, Cotton VE, Mendez-Bermudez A, Wig G, Medina-Calzada Z, Neumann R, Jeffreys AJ, Winney B, Wilson JF, Clark DA, Dyer MJ, Royle (2014) Nucleic Acids Research 42(1): 315-327.

Ingolia NT, Brar GA, Rouskin S, McGeachy AM, Weissman JS (2012) Nature protocols 7: 1534-1550.

Ingolia NT, Ghaemmaghami S, Newman JRS, Weissman JS (2009) Science 324: 218-223.

Karadağ Geçgel S, Ersoy A, Sevinir BB, Sınırtaş M, Göral G (2012) Mikrobiyoloji Bulteni 46(4): 594-606.

Kaul Z, Cesare AJ, Huschtscha LI, Neumann AA, Reddel RR (2012) EMBO 13: 52-59.

Kido S, Ozaki T, Asada H, Higashi K, Kondo K, Hayakawa Y, Morishima T, Takahashi M, Yamanishi K (1991) Journal of Clinical Microbiology 29(1): 76-79.

Kieff E (1996) $3^{\text {rd }}$ edition, Lippincott-Raven Press. Philadelphia.

Komano J, Sugiura M, Takada K (1998) Journal of Virology 72: 9150-9156.

Koslowski M, Sahin U, Mitnacht-Kraus R, Seitz G, Huber C, Tureci O (2007) Cancer Research 67: 9528-9534.

Lee CJ, Buznyk O, Kuffova L, Rajendran V, Forrester JV, Phopase J, Islam MM, Skog M, Ahlqvist J, Griffith M (2014) Translational Vision Science \& Technology May 29.3(3): 4 eCollection.

Lee MA, Diamond ME, Yates JL (1999) Journal of Virology 73: 2974-2982.

LeGoff J, Péré H, Bélec L (2014) Virology Journal 11: 83-99

Lehrer RI, Ganz T (2002) Current Opinion in Hematology 9: 18-22.

Liu Z, Zhang P, Tang S, He X, Zhang R, Wang X, Yuan Z, Tan J, Peng B, Liu E, Fu Z, Zou L (2014) BMC Infectious Diseases 14(1): 245-253.

Lockman PR, Mumper RJ, Khan MA, Allen DD (2002) Drug Development and Industrial Pharmacy 28(1): $1-13$.

Loens K, Bergs K, Ursi D, Goossens H, Ieven M (2007) Journal of Clinical Microbiology 45: 421-425.

Long SS (2013) Evidence-Based Medicine 18(2): doi 10.1136/eb-2012-100674.

Ma Y, Gao S, Wang L, Wang N, Li M, Zheng B, Qi Y, Sun Z, Liu W, Ruan Q (2013) Virology Journal. 10: 65-74.

McCannel CA, Holland GN, Helm CJ, Cornell PJ, Winston JV, Rimmer TG (1996) American Journal of Ophthalmology 121(1): 35-46.

Mettenleiter T, Keil G, Fuchs W (2008) In: Molecular Biology of Animal Herpesviruses, Animal Viruses: Molecular Biology. Caister Academic Press, UK.

Miari VF, Wall GR, Clark DA (2014) Article first published online: 2 May: doi 10.1002/jmv.23967 Wiley Periodicals, Inc.

Mullis KB, Faloona FA (1987) Methods in Enzymology 155: $335-350$.

Ogata M (2009) Journal of Clinical and Experimental Hematopathology 49: 57-67.
Pandori MW, Lei J, Wong EH, Klausner J, Liska S (2006) BMC Infectious Diseases 6: 104-112.

Peng C, Chen J, Tang W, Liu C, Chen X (2014) PLoS One. 2014 9(6): e99542.

Perandin F, Pollara CP, Gargiulo F, Bonfanti C, Manca N (2009) Diagnostic Microbiology and Infectious Disease 64: 158-165.

Polman CH, Reingold SC, Banwell B, Clanet M, Cohen JA, Filippi M, Fujihara K, Havrdova E, Hutchinson M, Kappos L, Lublin FD, Montalban X, O'Connor P, Sandberg-Wollheim M, Thompson AJ, Waubant E, Weinshenker B, Wolinsky JS (2011) Annals of Neurology 69(2): 292-302.

Potenza L, Luppi M, Barozzi P, Rossi G, Cocchi S, Codeluppi M, Pecorari M,Masetti M, Di Benedetto F, Gennari W, Portolani M, Gerunda GE, Lazzarotto T,Landini MP, Schulz TF, Torelli G, Guaraldi G (2008) The New England Journal of Medicine. 2008 359(6): 593-602.

Ranger-Rogez S, Vidal E, Liozon F, Denis F (1994) Clinical Infectious Diseases 19(6): 1159-1160.

Restrepo-Gualteros SM, Jaramillo-Barberi LE, GonzalezSantos M, Rodriguez-Martinez CE, Perez GF, Gutierrez MJ, Nino G (2014) Viruses 6(5): 2038-2051.

Rodrigues D, de-Paris F, Paiva RM (2013) Revista da Sociedade Brasileira de Medicina Tropical 46(5): $625-628$.

Rozenberg F, Lebon P (1991) Journal of Clinical Microbiology 29(11): 2412-2417.

Sanger F, Nicklen S, Coulson AR (1977) Proceedings of the National Academy of Sciences 74(12): 5463-5467.

Sarid R, Flore O, Bohenzky RA, Chang Y, Moore PS (1998) Journal of Virology 72: 1005-1012.

Sauerbrei A, Wutzler P (2007) Medical Microbiology and Immunology 196(2): 95-102.

Scanlan MJ, Gure AO, Jungbluth AA, Old LJ, Chen YT (2002) Immunological Reviews 188: 22-32.

Scheepers MA, Lecuona KA, Rogers G, Bunce C, Corcoran C, Michaelides M (2013) ScientificWorld Journal 22: 545149: doi 10.1155/2013/545149.

Shimizu N, Tanabe-Tochikura A, Kuroiwa Y, Takada K (1994) Journal of Virology 68: 6069-6073.

Siouda M, Frecha C, Accardi R, Yue J, Cuenin C, Gruffat H, Manet E, Herceg Z, Sylla BS, Tommasino M (2014) PLoS Pathogens 10(5): e1004125.

Soulier J, Grollet L, Oksenhendler E, Cacoub P, Cazals-Hatem D, Babinet P, d'Agay MF, Clauvel JP, Raphael M, Degos L, Sigaux F (1995) Blood. 86(4): 1276-1280.

Stern-Ginossar N, Weisburd B, Michalski A, Le VT, Hein MY, Huang SX, Ma M, Shen B, Qian SB, Hengel H, Mann M, Ingolia NT, Weissman JS (2012) Science 338: 1088-1093.

Strong MJ, O'Grady T, Lina Z, Xu G, Baddoo M, Parsons Ch, Zhang K, Taylor ChM and Flemington EK (2013) J Virol 87(23): 13059-13062.

Subak-Sharpe JH, Dargan DJ (1998) Virus Genes 16(3): 239-251.

Thompson MP, Kurzrock R (2004) Clinical Cancer Research 10: 803-821.

Van Der Pol B, Warren T, Taylor SN, Martens M, Jerome KR, Mena L, Lebed J, Ginde S, Fine P, Hook EW $3^{\text {rd }}$ (2012) Journal of Clinical Microbiology 50: 3466-3471. 
Voumvourakis KI, Kitsos DK, Tsiodras S, Petrikkos G, Stamboulis E (2010) Mayo Clinic Proceedings 85(11): 1023-1030.

Wald A, Huang M-L, Carrell D, Selke S, Corey L (2003) The Journal of Infectious Diseases 11: 1345-1351.

Wang X, Baddoo MC, Yin Q (2014) Virology Journal 11: $107-116$.

Whitby D, Howard MR, Tenant-Flowers M, Brink NS, Copas A, Boshoff C, Hatzioannou T, Suggett FE, Aldam DM, Denton AS, Miller RF, Weller IVD (1995) Lancet 346(8978): 799-802.

Whitley RJ, Roizman B (2001) Lancet 357(9267): 1513-1518.
Wilhelm J, Pingoud A (2003) ChemBioChem 4(11): $1120-1128$.

Yagasaki H, Kato M, Shimizu N, Shichino H, Chin M, Mugishima H (2011) Annals of Hematology 90(7): $851-852$.

Young LS, Dawson CW, Eliopoulos AG (2000) Molecular Pathology 53: 238-247.

Zhong M, Zheng K, Chen M, Xiang Y, Jin F, Ma K, Qiu X, Wang Q, Peng T, Kitazato K, Wang Y (2014) PLoS One 9(6): e99425.

Zhou W, Lin F, Teng L, Li H, Hou J, Tong R, Zheng C, Lou Y, Tan W (2013) PLoS One 8(11): e79477. 